\title{
Calretinin promotes invasiveness and EMT in malignant mesothelioma cells involving the activation of the FAK signaling pathway
}

\author{
Janine Wörthmüller ${ }^{1}$, Walter Blum ${ }^{1,2}$, Laszlo Pecze $^{1}$, Valérie Salicio ${ }^{1}$ and Beat \\ Schwaller ${ }^{1}$ \\ ${ }^{1}$ Unit of Anatomy, Section of Medicine, University of Fribourg, 1700 Fribourg, Switzerland \\ ${ }^{2}$ Genetica AG, 8001 Zurich, Switzerland \\ Correspondence to: Beat Schwaller, email: beat.schwaller@unifr.ch
}

Keywords: calretinin; malignant mesothelioma; FAK signaling; EMT

Received: August 19, $2018 \quad$ Accepted: October 25, $2018 \quad$ Published: November 20, 2018

Copyright: Wörthmüller et al. This is an open-access article distributed under the terms of the Creative Commons Attribution License 3.0 (CC BY 3.0), which permits unrestricted use, distribution, and reproduction in any medium, provided the original author and source are credited.

\section{ABSTRACT}

Calretinin (CR) is used as a positive marker for human malignant mesothelioma (MM) and is essential for mesothelioma cell growth/survival. Yet, the putative role(s) of CR during MM formation in vivo, binding partners or CR's influence on specific signaling pathways remain unknown. We assessed the effect of $C R$ overexpression in the human MM cell lines MSTO-211H and SPC111. CR overexpression augmented the migration and invasion of MM cells in vitro. These effects involved the activation of the focal adhesion kinase (FAK) signaling pathway, since levels of total FAK and phospho-FAK ( Tyr $^{397}$ ) were found up-regulated in these cells. CR was also implicated in controlling epithelial-to-mesenchymal transition (EMT), evidenced by changes of the cell morphology and up-regulation of typical EMT markers. Co-IP experiments revealed FAK as a new binding partner of CR. CR co-localized with FAK at focal adhesion sites; moreover, CR-overexpressing cells displayed enhanced nuclear FAK accumulation and an increased resistance towards the FAK inhibitor VS-6063. Finally, CR downregulation via a lentiviral shRNA against CR (CALB2) resulted in a significantly reduced tumor formation in vivo in an orthotopic xenograft mouse model based on peritoneal MM cell injection. Our results indicate that CR might be considered as a possible target for MM treatment.

\section{INTRODUCTION}

Malignant mesothelioma (MM) is a highly aggressive neoplasm that arises from mesothelial cells covering the surfaces of the pleura, peritoneum, and pericardium and is prevalently associated with asbestos exposure [1]. The prognosis is extremely poor mostly due to late diagnosis and lack of understanding of its biology and molecular pathogenesis. There is no effective treatment so far; median overall survival following frontline chemotherapy with pemetrexed and cisplatin is approximately 12 months [2], thus early diagnosis is critical, and prolonged survival can be best achieved among patients who are candidates for surgery [1]. The development of MM occurs after a long latency period, suggesting that multiple (genetic) events are required for tumorigenic conversion of mesothelial cells [3]. According to the WHO classification, $\mathrm{MM}$ is sub-classified as epithelioid (mostly composed of epithelial-shaped cells), sarcomatoid (composed of spindle-shaped cells), or biphasic (a mixture of both cell types) [4].

The $\mathrm{Ca}^{2+}$-binding protein calretinin (CR) serves as an undisputed marker for the diagnosis of $\mathrm{MM}$, in particular of the epithelioid type and the epithelioid parts of the mixed type [5, 6]. CR is essential for MM cell growth/survival in vitro, since its downregulation results in decreased cell proliferation and viability [7]. Overexpression of CR in immortalized mesothelial cells protects them from acute asbestos-induced cytotoxicity 
in vitro; thus, an increased survival of asbestos-exposed CR-expressing mesothelial cells may promote and favor MM development [8]. Regulation of CR expression is cell type-specific [9], yet little is known on the mechanisms and effects of CR up-regulation during early stages of mesotheliomagenesis.

Focal adhesion kinase (FAK) is overexpressed in various cancers including MM [10]. Activation of tyrosine kinases is essential in the progression from non-neoplastic mesothelial progenitor cells to mesothelioma [11] and FAK has been often described to promote malignancy by regulating tumorigenesis and metastasis through highly-coordinated signaling networks orchestrating invasion, EMT, angiogenesis and regulation of cancer stem cells [12]. Based on pre-clinical findings, FAK inhibition is of potential therapeutic interest and a number of FAK-directed small molecule inhibitors are currently undergoing clinical trials. EMT, characterized by acquisition of a mesenchymal phenotype, increased migratory and invasive potential, enhanced resistance to apoptosis, and increased production of extracellular matrix (ECM) components, is thought to represent an important step in cancer progression [13, 14]. Besides CR's wellknown function as a $\mathrm{Ca}^{2+}$-buffering protein, additional putative CR sensor functions (e.g. binding partners in MM cells) or CR's possible role(s) during EMT in MM development are largely unknown.

In this study we investigated the role of $\mathrm{CR}$ in $\mathrm{MM}$ cell lines by evaluating the effects of CR overexpression. Our results demonstrate the essential role of $\mathrm{CR}$ in promoting migration, invasion and EMT in vitro, likely with an involvement of FAK signaling, since FAK protein levels and the activated phosphorylated form $\mathrm{p}$-FAK $\left(\mathrm{Tyr}^{397}\right)$ were up-regulated in CR-overexpressing cells. We also validated CR downregulation as a promising strategy to impair MM progression in vivo in an orthotopic mouse model.

\section{RESULTS}

\section{CR overexpression promotes migration and invasion in vitro}

The effect of CR overexpression was investigated in SPC111 (low endogenous CR levels) and MSTO$211 \mathrm{H}$ cells (medium-to-high endogenous CR levels), both MM cell lines from the biphasic subtype. Strong lentivirus-mediated CR overexpression was evident in both lines (Figure 1A). No apparent differences in the morphology of the cells were observed after shortterm CR overexpression (data not shown). Although CR overexpression tended to initially increase cell proliferation (generally observed between passages 2-4), at later passages $(>5)$ no differences were observed when compared with the parental (wt) cells (Supplementary Figure 1A). Analyses of CR levels at early $(<10)$ and late passages $(>30)$ showed no significant changes in $\mathrm{CR}$ protein levels (Supplementary Figure 1B); if anything, a slight (insignificant) increase in CR levels was observed at later passages. Thus, lentiviral-mediated CR expression resulted in stable and permanently elevated CR expression levels of this protein in SPC111-CR and MSTO-CR cells. Since local invasion is the characteristic clinical feature of MM, and mesothelin, another typical marker of mesothelioma, increases migration and invasion in MM cells [15], the effect of CR overexpression on cell migration/proliferation and invasion was investigated. In a scratch wound assay, the closing of a gap of approximately $1 \mathrm{~mm}$ by cell proliferation and migration was monitored. Video/microscope-based scratch wound assays represent a robust technique to evaluate cell migration and invasion, presenting some advantages over the typical Boyden chamber assay [16]. Timelapse experiments revealed an accelerated and complete closing in both CR-overexpressing lines compared to the wt cells (Figure 1B). The effect was more pronounced in SPC111 cells. As proliferation rates were identical in wt and CR-overexpressing cells (Supplementary Figure 1A), differences in the wound closure times between CRoverexpressing and wt cells were attributed to differences in the migration capacity of the cells. On average, the closure of the wound was completed after $18 \mathrm{~h}$ with SPC111-CR cells, while SPC111-wt cells showed a significant delay, closing the wound after $38 \mathrm{~h}(\mathrm{p} \leq 0.0001)$ (Supplementary Figure 1C). For MSTO- $211 \mathrm{H}$ cells, the corresponding wound closure times of CR-expressing and wt cells were $10 \mathrm{~h}$ and $16 \mathrm{~h}$, respectively $(\mathrm{p} \leq 0.05)$ (Supplementary Figure 1C). Invasion was assessed with a modified wound-healing assay, where the gap was filled and cells were covered with a basement membrane matrix (Matrigel; $1 \mathrm{mg} / \mathrm{ml}$ ) substrate that mimics cell-matrix interactions in the tumor microenvironment. Both MM cell lines overexpressing $\mathrm{CR}$ were clearly more invasive than the corresponding wt cells (Figure 1C, 1D). SPC111-CR closed the wound almost completely after $90 \mathrm{~h}$, while in the case of MSTO-CR cells the closure of the wound was already complete after $60 \mathrm{~h}$ (see Supplementary Movies 1-4). Neither of the wt cells were capable of completely invading the gap space at any time point (measured up to $140 \mathrm{~h}$ ). Invasion was additionally measured with the Boyden chamber assay (Supplementary Figure 2). CRexpressing SPC111 cells showed significantly increased invasive potential compared to the corresponding wt cells, thus confirming the results obtained with the scratch assay (Figure 1). Of note, cell migration/proliferation was not different between SPC111 wt and SPC111-CR cells determined in this assay (Supplementary Figure 2).

\section{CR overexpression leads to FAK up-regulation and altered FAK localization}

Among proteins favoring tumor invasion, elevated FAK expression is associated with increased tumor 
A

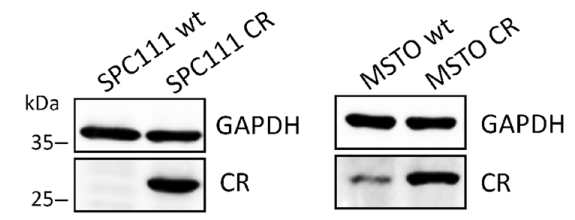

B
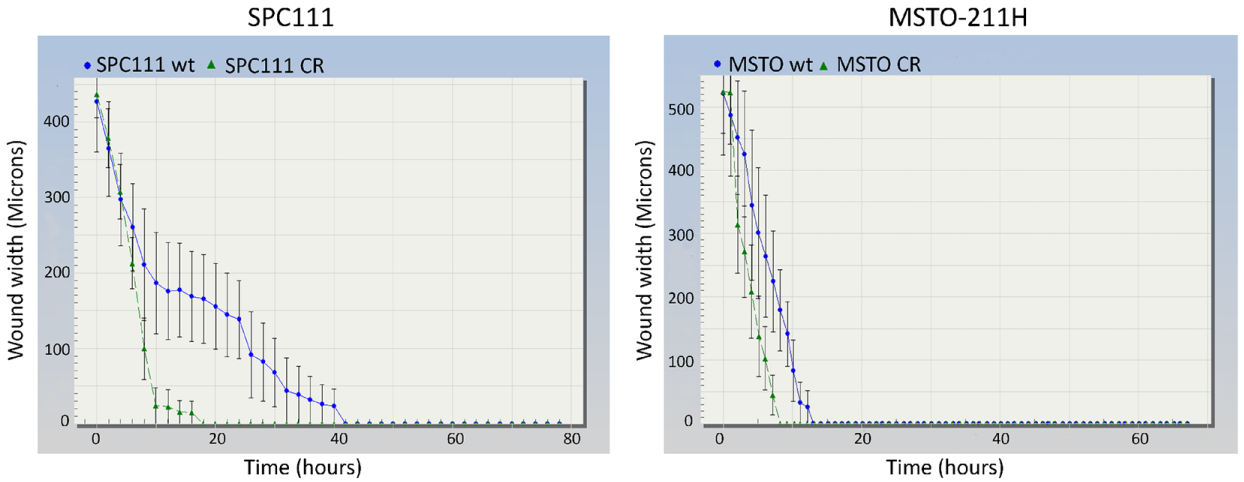

C
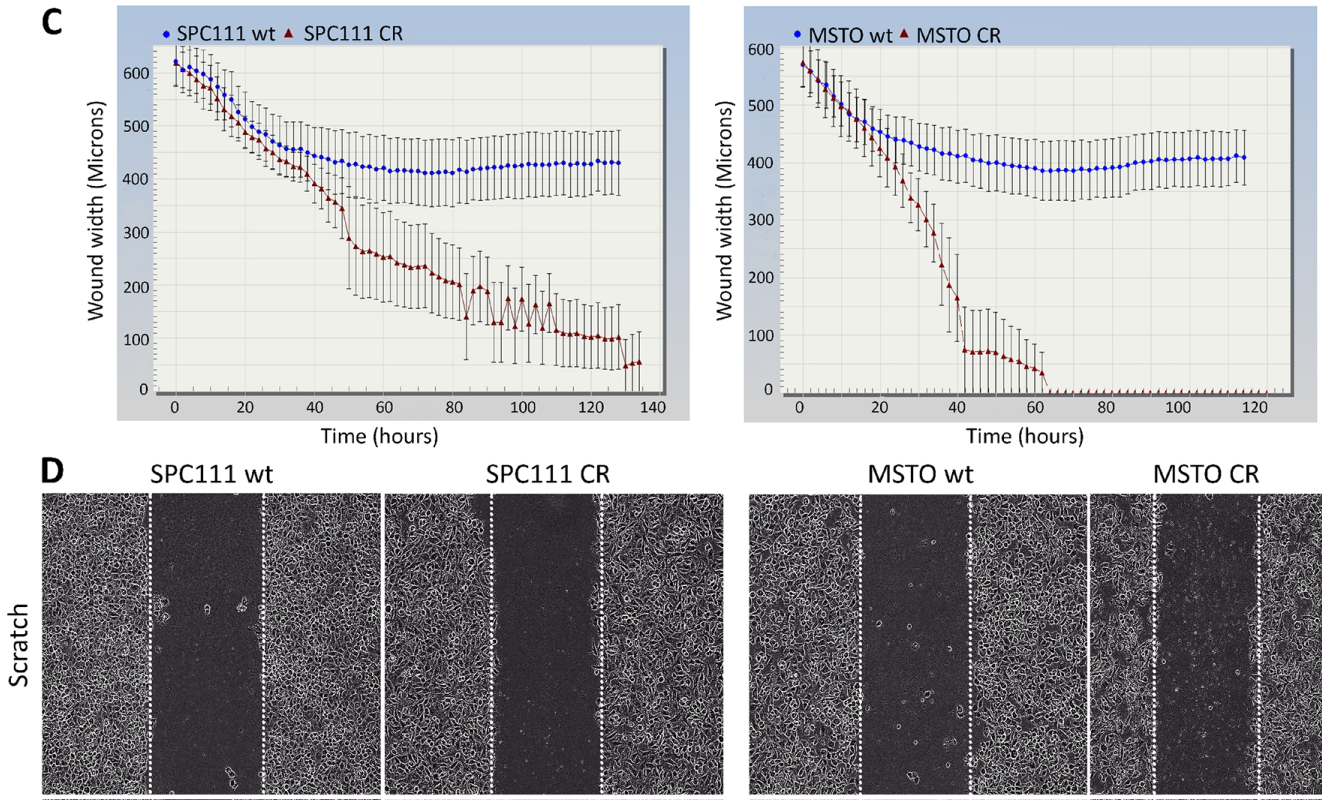

MSTO CR
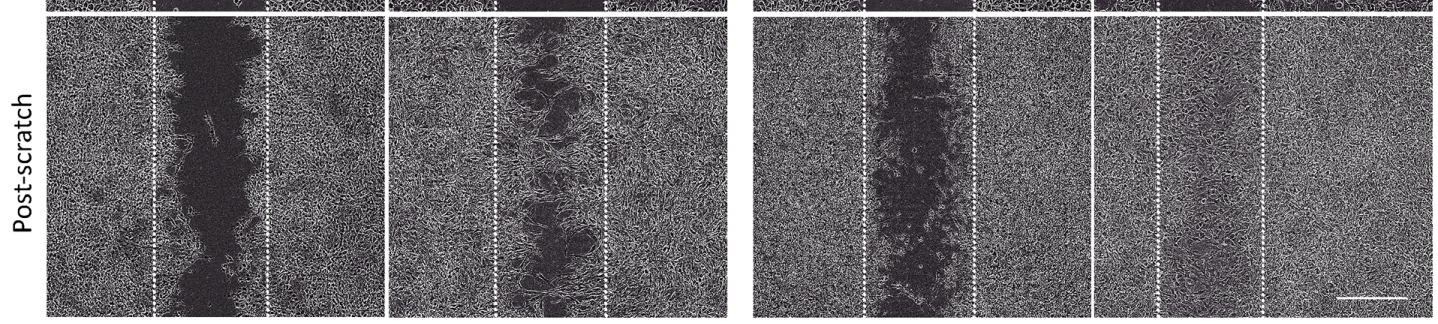

Figure 1: CR overexpression promotes migration and invasion in vitro. (A) Western Blot analysis demonstrating lentiviralmediated CR overexpression in SPC111 and MSTO-211H cells. GAPDH was used as loading control. (B) Comparison of wound closure kinetics between wt (blue) and CR- overexpressing cells (green) shown for SPC111 and MSTO-211H cells monitored with the IncuCyte ${ }^{\mathrm{TM}}$ imaging system every $2 \mathrm{~h}$. A faster closing of the scratch is observed for CR-overexpressing cells when compared with wt cells. (C) Invasiveness determined by a modified 'wound healing assay' with an added matrix barrier component (Matrigel ${ }^{\mathrm{TM}}$ ). Comparison of wound closure kinetics between wt (blue) and CR-overexpressing cells (red). CR-overexpressing SPC111 and MSTO-211H cells completely closed the wound after $90 \mathrm{~h}$ and $60 \mathrm{~h}$, respectively. Neither of the wt cells were capable of closing the gap during the observation period (140 h; $\mathrm{n}=4$ independent experiments). (D) Representative examples of time-lapse images taken after confluent monolayers of SPC111 and MSTO-211H (wt and CR-overexpressing cells) were scratched (time point $0 \mathrm{~h}$ ), and after $90 \mathrm{~h}$ and $60 \mathrm{~h}$ (post-scratch), respectively. Scale bar: $400 \mu \mathrm{m}$. 
invasiveness in several malignancies $[17,18]$. Total FAK levels were upregulated in CR-overexpressing SPC111 and MSTO-211H cells when compared with the corresponding wt cells (Figure 2A). Additionally, signals for phosphoFAK modified at the major autophosphorylation site $\mathrm{Tyr}^{397}$ were stronger in CR-overexpressing cells. Quantification of p-FAK $\left(\mathrm{Tyr}^{397}\right)$ Western Blot levels revealed a significant increase of approximately 50\% in SPC111-CR cells with respect to the corresponding wt cells $(\mathrm{p} \leq 0.01)$. A trend towards an increase of p-FAK $\left(\mathrm{Tyr}^{397}\right)$ levels was also observed in the case of MSTO-CR cells (increase of $27 \pm 12 \%$; n.s.). Analyses of the ratios p-FAK $\left(\mathrm{Tyr}^{397}\right) / \mathrm{FAK}$ revealed a significant increase $(1.314 \pm 0.001$ (normalized to $w t) ; p \leq 0.0001$ ) in MSTO-CR cells compared to wt cells. In SPC111 cells, this ratio was also slightly increased in CR-overexpressing SPC111 cells ( $1.076 \pm 0.071$; n.s.); the reason for not reaching significance in SPC111 cells is resulting from a nearly paralleled increase of both, p-FAK $\left(\right.$ Tyr $\left.^{397}\right)$ and total FAK. Total FAK levels were also clearly increased in epithelioid MM cells (ZL5 and ZL55) and to a lesser extent in the biphasic SPC212 and sarcomatoid ZL34 MM cells (Supplementary Figure 3A). However, in the latter two lines, signals for p-FAK $\left(\mathrm{Tyr}^{397}\right)$ were strongly increased in the CR-overexpressing cells (Supplementary Figure 3A). Besides increasing total FAK and p-FAK $\left(\mathrm{Tyr}^{397}\right)$ levels, CR overexpression also affected FAK's intracellular localization. In both MSTO-211H wt and -CR cells, CR immunofluorescence was distributed rather homogenous; nuclear CR staining was somewhat increased in MSTO-CR cells (Figure 2B). While CR levels in SPC111 wt cells were below the detection threshold, immunostaining intensity of CR-overexpressing cells was rather heterogeneous, likely the result of different copy numbers and integration sites of the transgene (Figure 2B). FAK staining was relatively weak and more confined to perinuclear regions of SPC111 and MSTO$211 \mathrm{H}$ wt cells. In both lines with elevated CR levels, CR and FAK showed a strong co-localization at the leading edge of the cells forming punctate-like patterns along the plasma membrane typical of focal adhesions. A similar colocalization was also observed in other CR-overexpressing MM lines (e.g. ZL55-CR and ZL5-CR; Supplementary Figure 3B). Unexpectedly, in both CR-overexpressing MM lines, nuclear FAK immunofluorescence was significantly increased, particularly evident in SPC111$\mathrm{CR}$ and to a lesser extent in MSTO-CR cells (Figure 2B).

\section{Nuclear FAK levels are increased in CR- overexpressing cells. Co-IP experiments reveal a direct interaction between CR and FAK}

Western Blots of nuclear extracts from CRoverexpressing MM cells showed stronger FAK signals than extracts from the corresponding wt cells (Figure $3 \mathrm{~A}$ ); the increase of approximately $30 \%$ was significant in SPC111 and MSTO-211H cells $(\mathrm{p} \leq 0.01)$. The increase was also evident in cells co-stained with DAPI and FAK resulting in cyan co-staining (Supplementary Figure 4). Since FAK and CR co-localized at focal adhesions and moreover in the nuclei of some CR-overexpressing MM cells (Figure 2B), we investigated putative interactions between FAK and $\mathrm{CR}$ by co-immunoprecipitation experiments. FAK was undoubtedly pulled down by CR antibodies indicative of direct physical interaction (Figure 3B). Additionally, FAK was co-immunoprecipitated with CR in MSTO wt cells, which endogenously express relatively high $\mathrm{CR}$ levels, thus precluding that the interaction might be an artifact taking place only in genetically modified (CR-overexpressing) cells (Figure 3C). The complementary experiment, $\mathrm{CR}$ being pulled down by FAK antibodies was negative using two different FAK antibodies (data not shown). This failure was attributed to FAK antibodies binding to an epitope in FAK overlapping with the $\mathrm{CR}$ interaction site and thus sterically hindering the interaction with $\mathrm{CR}$.

\section{Cells overexpressing CR exhibit an increased resistance towards the FAK inhibitor VS-6063}

Since FAK inhibitors decrease tumor growth and metastasis in preclinical models and in initial clinical trials in cancer patients $[19,20]$ and FAK expression/activity was increased in CR-overexpressing MM cells, cells were exposed to the FAK inhibitor VS-6063. When compared to the respective wt controls, CR-overexpressing cells of both cell lines were more resistant at higher concentrations $(\geq 5 \mu \mathrm{M})$ of the inhibitor (Figure 3D), evidenced by the increase in viability after $48 \mathrm{~h}$ (SPC111) and $72 \mathrm{~h}$ (MSTO$211 \mathrm{H})$ of treatment. Differences became most evident at the highest inhibitor concentration $(10 \mu \mathrm{M})$. These findings are in support of CR overexpression in MM cells leading to enhanced FAK signaling, subsequently requiring higher VS-6063 concentrations to decrease cell viability.

\section{CR overexpression induces EMT}

Cell invasion is considered a key step in metastasis resulting from various factors and altered oncogenic signaling pathways, which overlap with EMT-inducing pathways [21], often with an involvement of FAK [22]. Since transient CR expression in the mesenchyme occurs during normal embryonic development of the mouse lung [23], and CR expression is increased in mice subjected to bleomycin treatment resulting in EMT [24], we investigated the effect of long-term CR overexpression in MM cells on EMT. At the morphological level, CR overexpression in SPC111 cells resulted in a change from well-defined compact clusters (wt), to more loosely attached and often dispersed cells (Figure 4A). Likewise, MSTO-CR cells showed a loss in the connection of the cells with a change towards a more spindle-like morphology 

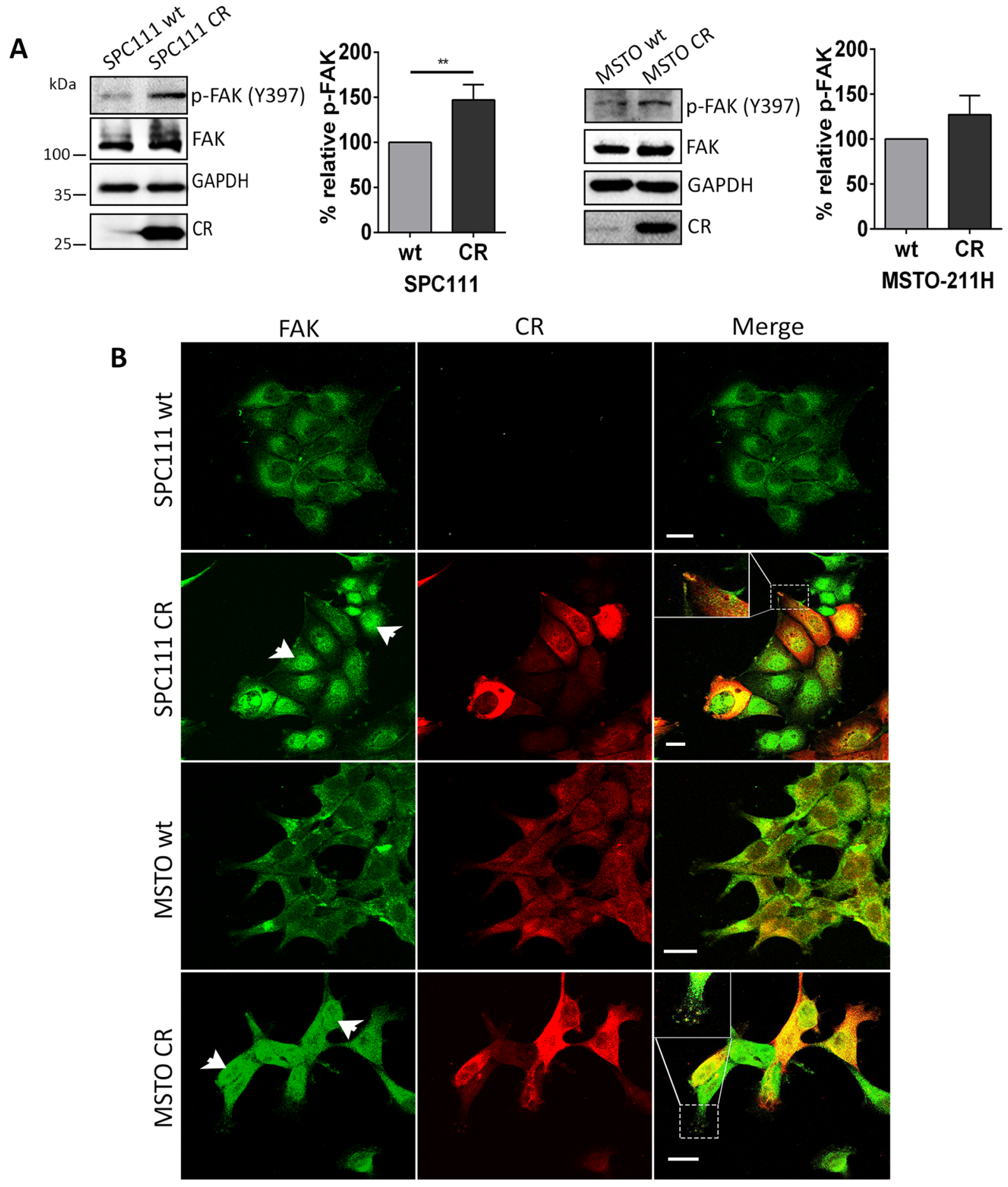

Figure 2: CR overexpression leads to FAK up-regulation and altered FAK localization. (A) Western Blot analysis of CRoverexpressing and wt MM cells revealed up-regulation of total FAK and p-FAK $\left(\mathrm{Tyr}^{397}\right)$ in SPC111 and MSTO-211H cells. Protein size markers are shown in the first Western Blot of the figure. GAPDH was used as loading control. Quantification of Western Blot signals for p-FAK ( $\mathrm{Tyr}^{397}$ ) is shown. p-FAK ( $\mathrm{Tyr}^{397}$ ) signals were increased by $\approx 50 \%$ in SPC111-CR and $\approx 40 \%$ in MSTO-CR with respect to the corresponding wt cells ( ${ }^{* *} \mathrm{p} \leq 0.01 ; \mathrm{n}=3$ independent experiments). (B) Representative confocal images from fixed cells stained for FAK (green) and CR (red) in wt and CR-overexpressing cells. In both cell lines CR co-localized with FAK (represented by yellow color in the merged images) in some parts of the cytosolic region and at the leading edge of cells forming punctate-like patterns (focal adhesions) along the plasma membrane. An enlarged image is shown on the top left of the merged image. CR-overexpressing cells exhibit nuclear FAK accumulation (arrowheads). Scale bar: $20 \mu \mathrm{m}$. 
when compared with wt cells. The prototypical epithelioid marker E-cadherin, its downregulation considered as a hallmark of EMT [25], was found decreased at the protein level in both CR-overexpressing MM lines, while $\mathrm{N}$-cadherin, a mesenchymal marker that increases during EMT, was upregulated (Figure 4B). A specific EMT pathway PCR array containing 84 key genes allowed further investigation of the role of CR on EMT (Figure 4C, 4D). Commonly downregulated transcripts in CR-
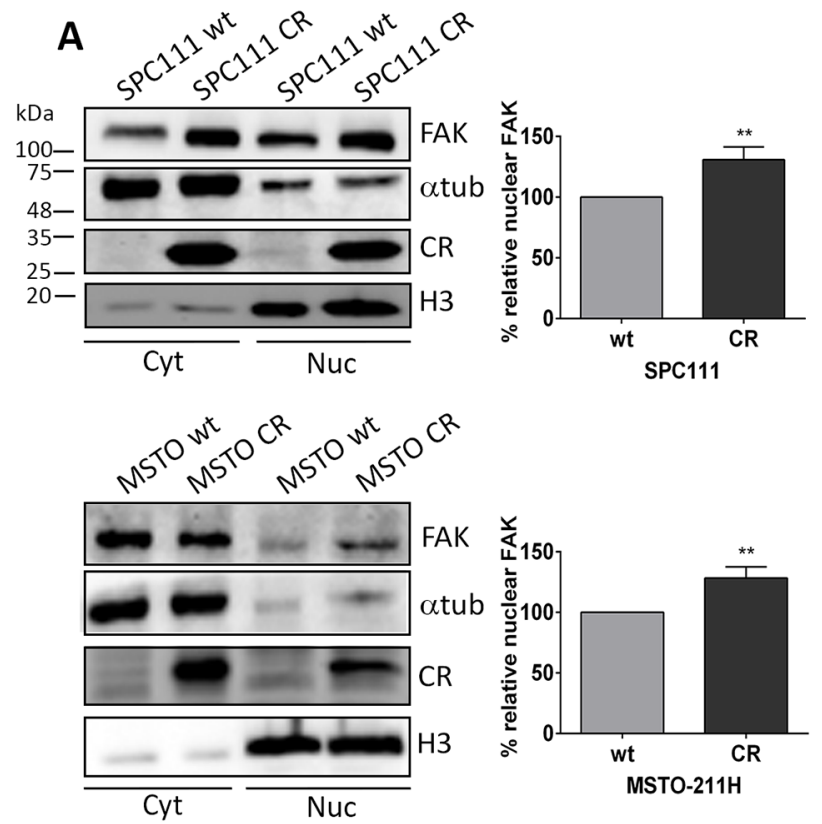

D

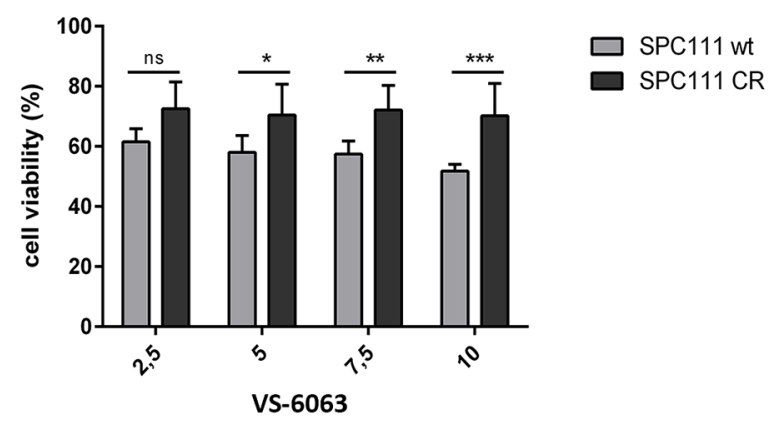

overexpressing MM cells included typical epithelial markers as CDH1 (E-cadherin); KRT7, a cytokeratin associated with a basal phenotype [13] and OCLN (occludin), which controls epithelial tight junctions. Also FGFBP1 encoding Fibroblast Growth Factor Binding Protein 1, a protein implicated in EMT, was decreased. Genes up-regulated in both cell lines were $B M P 2$, a bone morphogenetic protein, known to promote motility and invasion in several cancers [25], VCAN (Versican),

\section{B}
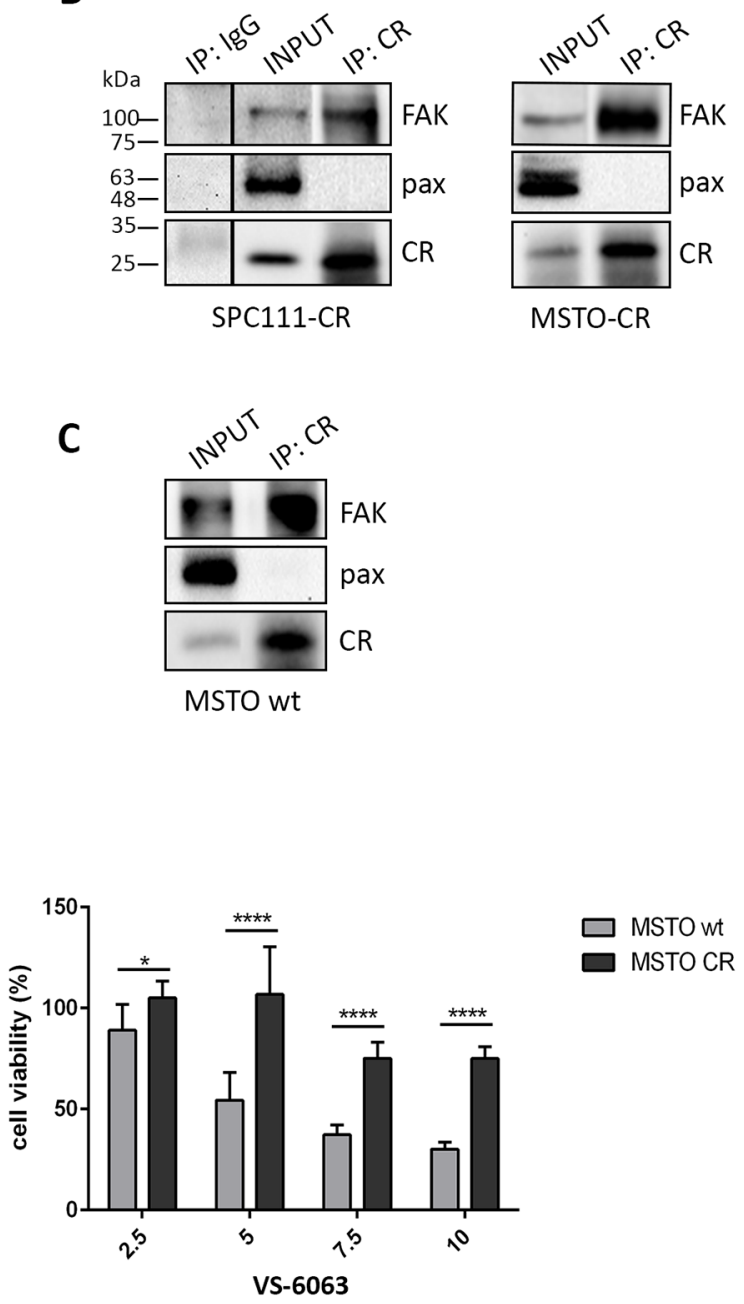

Figure 3: CR-expressing cells show increased nuclear FAK levels and an increased resistance towards the FAK inhibitor VS-6063; Co-IP experiments reveal an interaction between CR and FAK. (A) Western Blot analysis of cytosolic and nuclear protein extracts demonstrated an increase of nuclear FAK levels in both CR-overexpressing MM cell lines when compared with wt cells. Protein size markers are shown in the first Western Blot of the figure. $\alpha$-Tubulin and Histone H3 antibodies were used to demonstrate enrichment of these proteins in cytoplasmic and nuclear protein fractions, respectively. In the graphs the relative percentage of nuclear FAK expression levels is represented $\left({ }^{* *} \mathrm{p} \leq 0.01 ; \mathrm{n}=3\right.$ independent experiments). (B) Co-IP experiments with cellular lysates from SPC111-CR, MSTO-CR and (C) MSTO wt cells. FAK/CR complexes were co-immunoprecipitated with CR antibodies. A sample collected prior to IP is shown as INPUT. A normal rabbit polyclonal IgG was used as a negative IP control. Western Blot analysis was performed using anti-CR, anti-FAK and anti-paxillin (negative control for CR-binding) antibodies. Representative blots from 3 independent experiments. (D) Cell viability measured with the MTT assay ( $48 \mathrm{~h}$ for SPC111 and $72 \mathrm{~h}$ for MSTO-211H cells) after treatment with the FAK inhibitor VS-6063 at different concentrations ranging from $2.5 \mu \mathrm{M}$ to $10 \mu \mathrm{M}$. CR-overexpressing cells of both cell lines showed an increased resistance towards the inhibitor when compared with wt cells $\left(\mathrm{n}=3\right.$ independent experiments; asterisks represent ${ }^{*} \mathrm{p} \leq 0.05,{ }^{* *} \mathrm{p}$ $\leq 0.01,{ }^{* * *} \mathrm{p} \leq 0.001,{ }^{* * * *} \mathrm{p} \leq 0.0001$, respectively). 
a chondroitin sulfate proteoglycan that modulates cell proliferation, differentiation and adhesion [26] and the EMT marker TWIST1. Genes up-regulated more than 2-fold in MSTO-CR cells included FOXC2 (forkhead box $\mathrm{C} 2$ ) and JAG1 (protein-jagged1), both involved in the Notch signaling pathway and known to be increased during EMT [13, 25], MMP9 (Matrix MetalloPeptidase 9), an important extracellular matrix-degrading enzyme that enables invasion [25], as well as SERPINE1 and STEAP1, genes involved in ECM processes and cell adhesion. Also signals for SNAII (encoding the transcription factor Snail), which controls tumor growth and stemness and is

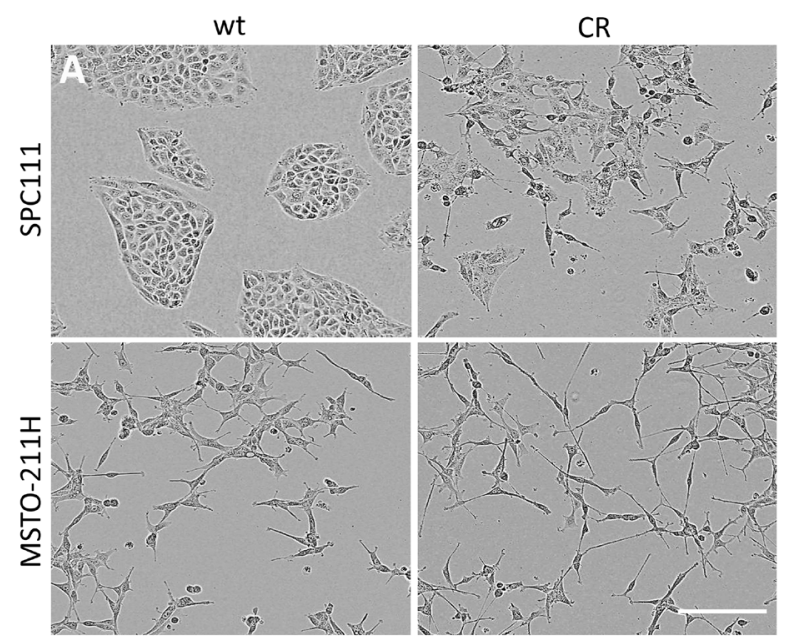

\section{B}
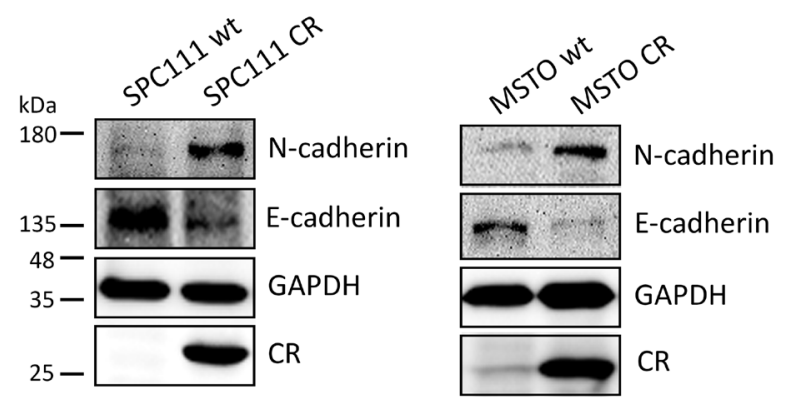

C
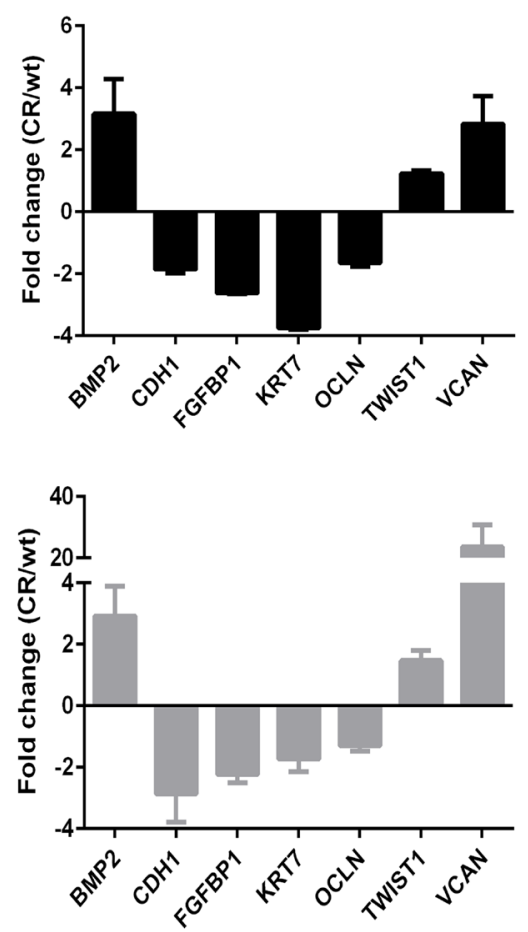

SPC111
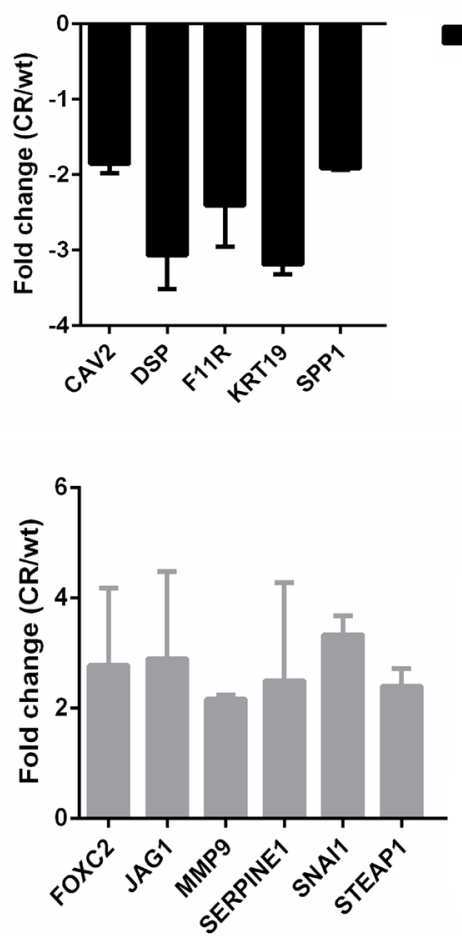

MSTO-211H

Figure 4: CR overexpression in MM cells induces EMT. (A) Representative images of wt and long-term CR-overexpressing MM cells. SPC111-CR cells showed loss of the typical clustered morphology and cell scattering. MSTO-CR cells exhibited an increased spindle-like phenotype. Scale bar: $400 \mu \mathrm{m}$. (B) Western Blot analysis of the epithelial marker E-cadherin and the mesenchymal marker $\mathrm{N}$-cadherin in wt and CR-overexpressing cells. CR overexpression induced a reduction of E-cadherin and an increase in N-cadherin when compared with wt cells. GAPDH was used as loading control. (C) Relative fold-change of transcript expression determined by an EMT pathway-specific PCR array (mean \pm SD from 2-3 independent experiments). Transcripts similarly up- and downregulated in both SPC111CR (black) and MSTO-211H-CR (gray) in comparison to their wt cells are shown in (C); differently expressed transcripts in either MM cell line are shown in (D) 
considered as typical EMT marker, were augmented in MSTO-CR cells. Transcripts downregulated in SPC111CR cells included $C A V 2$ encoding the potent tumor suppressor caveolin-2, SPP1 (osteopontin) and cytokeratin 19 (KRT19), as well as DSP and F11R, genes implicated in the organization of desmosomes and tight junctions, respectively [13, 25]. Other up- and/or downregulated genes are summarized in Table 1. Thus, increased invasiveness of CR-overexpressing MM cells is the likely consequence of an EMT process.

\section{CR downregulation in vivo impairs tumor progression in a MM orthotopic xenograft mouse model}

Since CR downregulation by CALB2 shRNAs decreases cell growth and viability in MM cells in vitro [7], we investigated the effect of CR downregulation within an appropriate tumor microenvironment in an orthotopic mouse model. Animals were randomized into two groups and MSTO-211H-Rluc cells $\left(1.5 \times 10^{6}\right)$ transduced $24 \mathrm{~h}$ earlier with a lentiviral vector containing an shRNA against GFP (control group) or against CR (test group) were injected intraperitoneally. As reported previously, bioluminescent imaging (BLI) in MM was used to non-invasively quantify tumor burden and progression [15]. At day 16 post-injection (p.i.) both mouse groups presented an equivalent BLI signal. At day 30 p.i., tumors had significantly grown in the control shGFP group, but remained unchanged in the shCALB2 group (Figure 5A, 5B). Constitutive downregulation of CR in MSTO-211H (wt) cells in vitro resulted in a reduction of $\approx 90 \%$ at the protein level and a similar decrease in total FAK levels (Figure 5C). Tissue samples from MSTO$211 \mathrm{H}$-injected mice (both shGFP and shCALB2) were histologically examined. In mice exposed to shGFPtreated (control) MSTO-211H cells, strongly stained CRir cells infiltrating the skeletal muscle of the diaphragm and the parietal peritoneal wall were observed (Figure $5 \mathrm{D}$, upper panels) indicative of high invasiveness. The injection of shCALB2-treated cells did not result in significant changes of the mesothelium of the parietal wall; the few adherent CR-ir MSTO- $211 \mathrm{H}$ cells mostly formed a single cell layer. On the surface of the peritoneal side of the diaphragm, a thickening of the mesothelium by proliferating MSTO-211H cells was evident; however, no cell infiltration of the skeletal muscle layer was observed in any of the shCALB2-treated mice (Figure 5D, lower panels). Additionally, in mice injected with shCALB2treated MSTO- $211 \mathrm{H}$ cells, FAK staining of the tumor cells mostly confined to the thickened tunica serosa was weaker (Figure 5E, lower panel) than in mice injected with the shGFP-MSTO-211H cells (Figure 5E, upper panel). CRexpressing tumor cells infiltrating the muscle tissue were also stronger stained for FAK, in line with the in vitro results shown in Figure 5C. Thus, MSTO-211H cells with higher CR and subsequently higher FAK levels showed a higher propensity for tumor cell infiltration in the muscle tissue underneath the tunica serosa.

\section{DISCUSSION}

Mechanisms implicated in the transformation of mesothelial cells to MM are still poorly understood. Pathways dysregulated in MM are related to proliferation, differentiation, migration and invasion, survival, apoptosis, cell cycle control and metabolism, often accompanied by mutations in cell cycle control $(C D K N 2 A)$ and tumor suppressor genes (BAP1 and NF2) [27]. However, the interactions among all these pathways and/or altered genes, as well as their exact role during MM pathogenesis remain unclear. Differential protein expression profiles between benign control and crocidolite-treated Met-5A mesothelial cells revealed activation of pathways related to DNA damage repair and cell cycle regulation and comparison between Met-5A and MM cells (NCI-H28) showed increased activation of the EGFR/ERK and PI3K/ AKT pathways [28].

$\mathrm{CR}$ is transiently expressed in lung mesenchyme and developing mesothelial cells [29], undetectable in the normal mesothelium, however reappearing in reactive mesothelial cells in vivo and immortalized mesothelial cells in vitro. These findings together with the presence of $\mathrm{CR}$ in epithelioid MM and the epithelioid part of biphasic MM [5, 6] are indicative of an involvement of CR in the initial processes of carcinogenesis. Increasing SV40 early region gene products (TAg, tAg) cause CR up-regulation in Met-5A cells resulting in increased resistance towards acute asbestos-induced cytotoxicity in vitro; the same holds true, when directly overexpressing CR [8]. The higher survival of asbestos-exposed high CR-expressing Met-5A cells is mainly mediated through the PI3K/AKT signaling pathway assumed to promote and favor MM development. CR regulation is different in neurons and non-neuronal cell types; in CR-positive colon cancer cells, CR expression is downregulated by butyrate [9] mostly functioning as a histone deacetylase (HDAC) inhibitor [30, 31]. In human MM cells, NRF-1 and E2F2 act as specific trans-activating factors binding to the $C A L B 2$ promoter $(-161 /+80 b p)$ [32]. In the promoter region of another MM marker gene MSLN encoding mesothelin, a "cancerspecific" element driving mesothelin overexpression in cancers was discovered [33]. When introducing this MSLN promoter element upstream of the large T antigen gene in the transgenic MexTAg mouse model [34], the promoter becomes active in asbestos-exposed mesothelial cells, leading to asbestos-induced mesotheliomas. Further studies to identify possible asbestos-induced "cancerspecific" promoter elements that are able to up-regulate CR in "primed" and/or early transformed MM cells are needed. 
Table 1: Up- and downregulated genes associated with CR overexpression in MM cells

\section{SPC111}

Gene

Gene full name

Related gene function*

Fold change

\begin{tabular}{|c|c|c|c|}
\hline ERBB3 & $\begin{array}{l}\text { v-erb b2 erythroblast leukemia } \\
\text { viral oncogene homolog } 3\end{array}$ & $\begin{array}{l}\text { Differentiation \& development; Cell growth \& } \\
\text { proliferation; Extracellular matrix \& cell adhesion; } \\
\text { Receptor tyrosine kinase signaling pathway. }\end{array}$ & -1.5 \\
\hline ESR1 & Estrogen receptor 1 & $\begin{array}{c}\text { Transcription factor; Estrogen-receptor signaling } \\
\text { pathway. }\end{array}$ & -2 \\
\hline IGFBP4 & $\begin{array}{l}\text { Insulin-like growth factor } \\
\text { binding protein } 4\end{array}$ & $\begin{array}{l}\text { Up-regulated during EMT; Cell growth \& } \\
\text { proliferation. }\end{array}$ & 2.5 \\
\hline MAP1B & $\begin{array}{l}\text { Microtubule Associated Protein } \\
\text { 1B }\end{array}$ & Cytoskeleton. & 1.6 \\
\hline
\end{tabular}

\section{MSTO-211H}

Gene Gene full name

\section{Related gene function}

Fold change

\begin{tabular}{|c|c|c|c|}
\hline ERBB3 & $\begin{array}{l}\text { v-erb b2 erythroblast leukemia } \\
\text { viral oncogene homolog } 3\end{array}$ & $\begin{array}{l}\text { Differentiation \& development; Cell growth \& } \\
\text { proliferation; Extracellular matrix \& cell adhesion; } \\
\text { Receptor tyrosine kinase signaling pathway. }\end{array}$ & -1.5 \\
\hline CAMK2N1 & $\begin{array}{l}\mathrm{Ca}^{2+} / \text { calmodulin-dependent } \\
\text { protein kinase II inhibitor } 1\end{array}$ & Up-regulated during EMT. & 2 \\
\hline DSC2 & Desmocollin 2 & Extracellular matrix \& cell adhesion. & -1.7 \\
\hline IL1RN & $\begin{array}{c}\text { Interleukin } 1 \text { Receptor } \\
\text { Antagonist }\end{array}$ & Downregulated during EMT. & -1.6 \\
\hline MSTR1 & $\begin{array}{l}\text { Macrophage stimulating } 1 \\
\text { receptor }\end{array}$ & $\begin{array}{l}\text { Downregulated during EMT; Migration \& motility; } \\
\text { Cell differentiation \& development; Cell growth \& } \\
\text { proliferation. }\end{array}$ & -2 \\
\hline PDGFRB & $\begin{array}{l}\text { Platelet-derived growth factor } \\
\text { receptor, beta polypeptide }\end{array}$ & $\begin{array}{l}\text { Cell growth \& proliferation; Migration \& motility; } \\
\text { Receptor tyrosine kinase signaling pathway. }\end{array}$ & -1.6 \\
\hline TGFB1 & $\begin{array}{l}\text { Transforming growth factor, } \\
\text { beta } 1\end{array}$ & $\begin{array}{l}\text { Morphogenesis; Cell growth \& proliferation; } \\
\text { Migration \& motility; TGF } \beta / \text { BMP signaling } \\
\text { pathways. }\end{array}$ & 1.5 \\
\hline TMEFF1 & $\begin{array}{c}\text { Transmembrane protein with } \\
\text { EF-like and two follistatin-like } \\
\text { domains }\end{array}$ & $\begin{array}{c}\text { Up-regulated during EMT; Differentiation \& } \\
\text { development. }\end{array}$ & 1.6 \\
\hline TMEM132A & Transmembrane protein $132 \mathrm{~A}$ & Up-regulated during EMT. & 1.7 \\
\hline
\end{tabular}

A pathway often dysregulated in many cancers is the FAK signaling pathway. FAK clusters at focal adhesion structures and regulates cancer-associated processes, including adhesion, migration and invasion [35]. Here we show that CR overexpression in MM cells increased total FAK levels and more importantly, FAK tyrosine phosphorylation at the major FAK auto-phosphorylation site $\mathrm{Tyr}^{397}$. Levels of $\mathrm{p}$-FAK $\left(\mathrm{Tyr}^{397}\right)$ are considered as proxy measure for augmented FAK signaling [22]. In line, MSTO-CR and SPC111-CR cells with higher p-FAK levels showed higher resistance to the FAK inhibitor VS-
6063 , likely the result of increased FAK signaling in CRoverexpressing cells. Moreover, FAK expression and key activation phosphorylation sites $\mathrm{Tyr}^{397}$ and $\mathrm{Tyr}^{576}$ are often elevated in invasive human cancers [12].

The mechanism how elevated CR levels increase FAK expression and/or FAK phosphorylation in MM cells is currently unknown, yet regulation of FAK is an area of intensive investigation. The expression and/or function of FAK "is tightly controlled via modulation of gene expression, competing alternatively spliced forms, noncoding RNAs, and proteins that directly or indirectly affect 


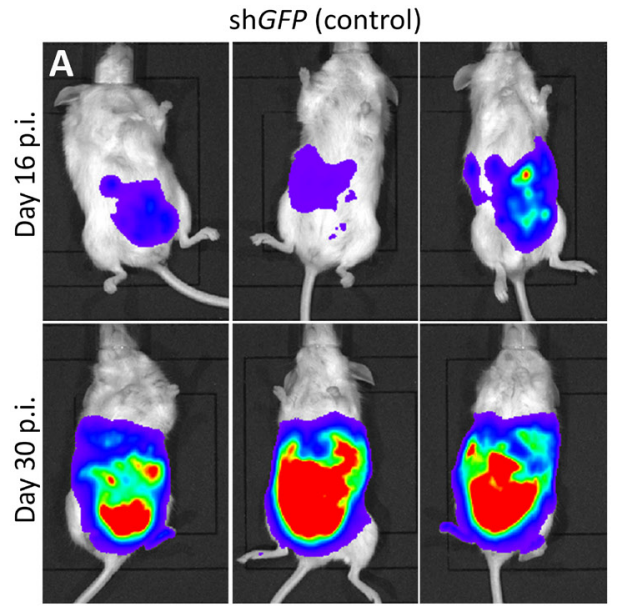

B
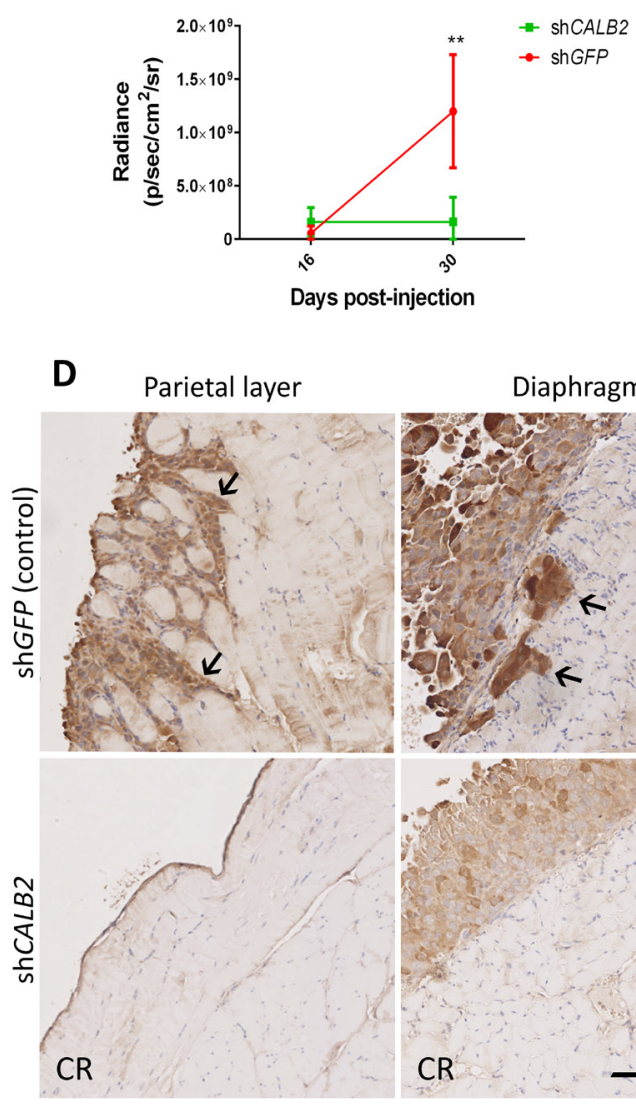

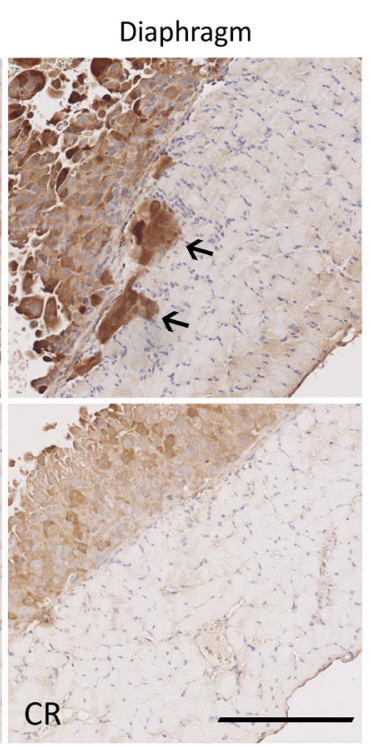

ShCALB2
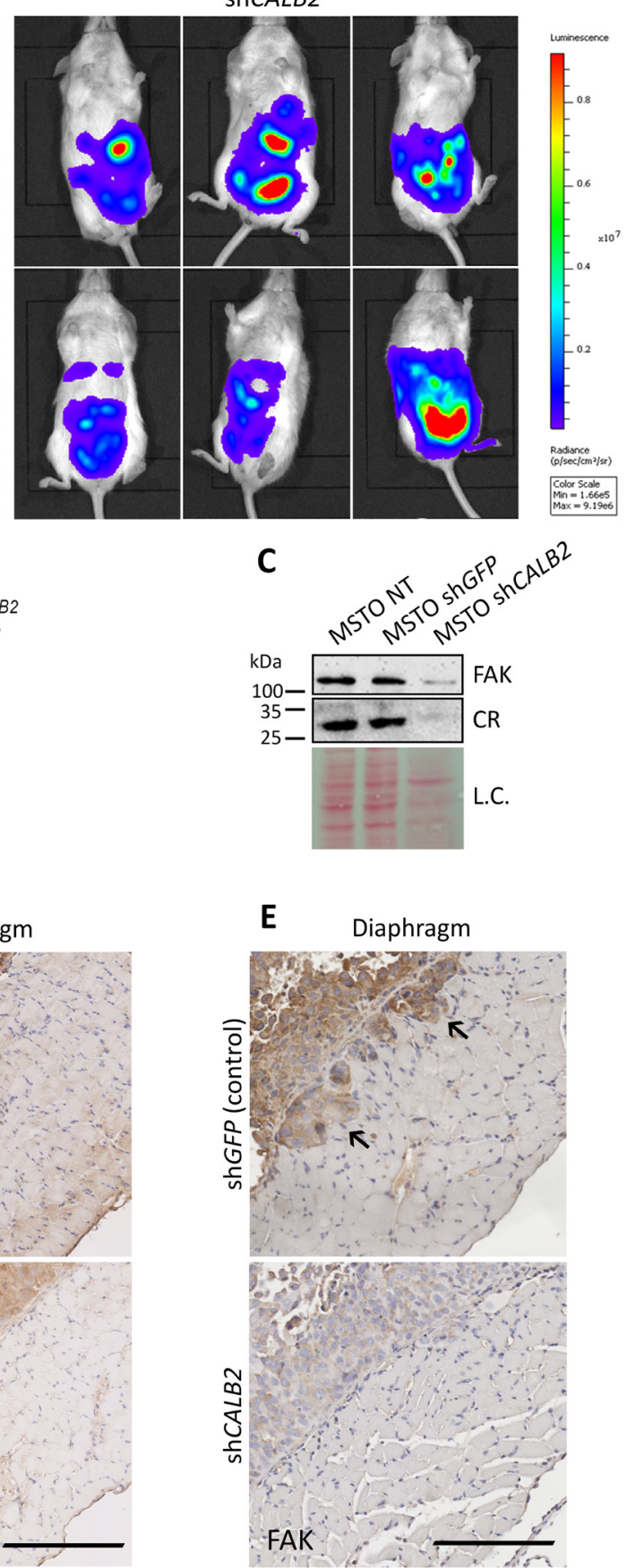

Figure 5: CR downregulation in vivo impairs tumor progression in a MM orthotopic xenograft mouse model. (A) Representative bioluminescence images of tumor burden in NSG mice inoculated with MSTO-211H-Rluc cells pre-treated with a lentiviral vector containing either an shRNA against GFP (control group) or against CALB2 (test group). Mice were scanned at days 16 and 30 p.i. At day 30 p.i., mice treated with shCALB2 showed a decrease in the tumor growth when compared with the control group (treated with shGFP). (B) Quantitative analyses of data shown in A. Mean bioluminescent signals (photons $/ \mathrm{s} / \mathrm{cm}^{2} / \mathrm{sr}$ ) obtained from both groups. At day 30 p.i., the shCALB2 group showed a significant reduction $\left({ }^{* *} \mathrm{p} \leq 0.01\right)$ in the tumor burden when compared with the control group. (C) Western Blot analysis demonstrated CR downregulation in vitro after 3 days of shCALB2 but not shGFP transduction in MSTO-211H wt cells. In parallel, a decrease of total FAK protein levels after shCALB2 treatment was observed. Ponceau Red staining intensity was used as loading control (L.C.). (D) Immunohistochemical staining of CR in the peritoneal parietal layer and diaphragm and E. of FAK in the diaphragm from representative sections taken from both groups at day 30 p.i. Arrows denote CR-positive and FAK-positive cells infiltrating the skeletal muscles of the parietal wall and/or the diaphragm present only in the shGFP group. Scale bar: $250 \mu \mathrm{m}$. 
kinase activation or protein stability" (reviewed in [36]). Some of the above processes of FAK regulation might also be operational in the case of CR. CR functions as a transcriptional co-regulator by binding to the promoter of SEPT7 coding for the protein septin 7 [37]. A similar mechanism might be envisaged also for the PTK2 (FAK) promoter. The $C A L B 2$ gene is also subject to alternative splicing producing among others also the transcript $C A L B 2 b$, likely acting as a long non-coding RNA [38]. Finally the interaction of CR with FAK at adhesion sites and/or in the nucleus as reported in this study might result in a protein complex (possibly together with additional proteins) involved in the regulation of FAK expression. These different possibilities should be investigated in further studies.

In CR-overexpressing MM cells, CR not only colocalized with FAK at focal adhesions sites, but both proteins physically interacted, evidenced by Co-IP experiments. Besides CR's function as a $\mathrm{Ca}^{2+}$ buffer, direct binding partners including the pore forming unit of the $\mathrm{P} / \mathrm{Q}$ type $\mathrm{Ca}^{2+}$ channel and a mutant form of huntingtin have also been identified $[39,40]$; for more details about CR's sensor functions, see [41]. CR and paxillin, a focal adhesion-associated protein that functions downstream of FAK as an adaptor protein recruiting diverse cytoskeletal and signaling proteins into an adhesion complex [42], share a common motif, the so-called LD domain [43]. Paxillin's LD2 and LD4 motifs function as FAK-binding sites $[44,45]$ and show high homology to the C-terminal part of CR's EF-hand 5 (Supplementary Figure 5). Thus, we hypothesize that CR might interact with its LD domain to FAK, presumably competing with paxillin binding and modifying FAK-paxillin signaling.

CR overexpression also affected FAK localization by targeting FAK to the nucleus. Besides the canonical roles for FAK, the role of nuclear FAK in regulating cancer cell proliferation and motility is slowly emerging [22]. FAK contains putative nuclear localization sequences (NLS) within the F2 lobe of its FERM domain and can localize to the nucleus, e.g. upon cellular stress, where it binds to p53 [46]. Reported nuclear FAK functions include transcriptional regulation of inflammatory cytokines and chemokines that promote an immuno-suppressive, protumorigenic microenvironment [47]. Due to the wellestablished role of FAK promoting tumor malignancy, pharmacological blocking of FAK signaling by compounds such as VS-6063 is currently investigated in clinical trials. The increased resistance of CR-overexpressing MM cells to VS-6063 observed in this study is thus assumed to be the result of CR-mediated up-regulation of FAK signaling.

CR overexpression also increased migration and more important invasion of MM cells, likely associated with this enhanced FAK signaling activity. FAK signalingmediated effects on cell migration and driving cell invasion are well characterized (reviewed in [12]). Tumor invasion by the penetration of cancer cells through the ECM and into neighboring tissue, requires combined effects of enhanced cell motility and alterations in the dynamics of focal adhesions, together with proteolytic degradation of the matrix $[48,49]$, e.g. by matrix metallopeptidases such as MMP9, shown to be increased in MSTO-CR cells. In support of a role of FAK in increasing the invasiveness, strongly stained FAK-immunoreactive cells were found infiltrating the diaphragm of mice injected with the control shGFP-MSTO cells. Increased FAK is also an essential mediator of EMT [22]. In both MM cell lines, CR-mediated up- and downregulation of specific EMT markers indicating that $\mathrm{CR}$ appears to control EMT through multiple pathways and downstream targets. This includes the up-regulation of transcription factors such as twist family bHLH transcription factor 1 (TWIST1) and snail family transcriptional repressor 1 (SNAI1), as well as an increase of $B M P 2$, known to promote motility and invasion. While the effect of CR overexpression on motility was rather mild, the effects on invasion were more striking. Neither of the wt MM cell lines was capable of closing the gap in the in vitro invasion assay, while CR-overexpressing ones completely recolonized the Matrigel-filled gap. In support, in vivo invasiveness of MSTO-211H cells was strongly decreased upon CR downregulation. Other differentially expressed genes included genes related with proliferation ( $V C A N, F O X C 2$, $J A G 1)$. CR-mediated downregulation of genes associated with an epithelial phenotype included E-cadherin ( $\mathrm{CDH} 1$, also shown at the protein level, Figure 4B), cytokeratins (KRT7, KRT19), and occludin (OCLN). In line with CRinduced EMT, CR-overexpressing cells were only loosely connected to each other and most had a spindle-shaped morphology.

CR up-regulation at early stages of MM pathogenesis, possibly mediated by asbestos-induced specific transcriptional programs, leads to the activation and up-regulation of the FAK signaling pathway, inducer of migration, invasion and EMT. Decreased tumor growth and invasiveness in vivo of MM cells with blocked CR expression reveals CR downregulation as a novel strategy to treat MM, likely in combination with the existing ones (cisplatin, pemetrexed). Reduced CR levels are expected to additionally increase the susceptibility to FAK inhibitors, drugs already being tested in clinical trials.

\section{MATERIALS AND METHODS}

\section{Cell culture}

Human mesothelioma (MSTO-211H), HeLa and HEK293T cells were obtained from the American Type Cell Collection (ATCC, Rockville, MD). Human mesothelioma cell lines SPC111, ZL5, ZL55, SPC212 and ZL34, were obtained from the University Hospital of Zurich (Switzerland) [50]. HeLa and HEK293T cells were maintained in DMEM medium supplemented with 
10\% FBS (Gibco, Basel, Switzerland) and 1\% Penicillin/ Streptomycin solution (1\% PS; Gibco); all others in RPMI1640 (Sigma-Aldrich, Buchs, Switzerland) containing $10 \%$ FBS supplemented with $2.5 \mu \mathrm{g} / \mathrm{ml}$ Amphotericin B (Corning, NY, USA). All cells were maintained at $37^{\circ} \mathrm{C}$ in a humidified $5 \% \mathrm{CO}_{2}$ atmosphere.

\section{Lentiviral (LV) constructs, vector production and lentivirus isolation}

For CR overexpression, pLV-CALB2 was used [23]; and for CR downregulation CALB2 shRNAs [7]. pLKO.1-shGFP (plasmid \#30323) was obtained from Addgene. Lentivirus particles were produced as described before [7]. Briefly, HEK293T cells were co-transfected by the $\mathrm{CaPO}_{4}$ method with $3 \mu \mathrm{g}$ of the envelope plasmid pMD2.G-VSVG (Addgene plasmid \#12259), $8 \mu \mathrm{g}$ of the packaging plasmid psPAX2 (Addgene plasmid \#12260) and $10 \mu \mathrm{g}$ of the transfer plasmid. Lentivirus in the supernatant of HEK293T cells was harvested $48 \mathrm{~h}$ and $72 \mathrm{~h}$ after transfection. The supernatant was filtered $(0.45$ $\mu \mathrm{m})$ and resuspended in DMEM containing 10\% FBS and $1 \%$ PS solution. To stably express Renilla Luciferase in MSTO-211H cells the GFP cassette in pLVTHM was replaced with a cDNA coding for the Renilla luciferase pGL4.74[hRluc/TK] (Promega). Briefly, the plasmid was digested with HindIII, filled with Klenow enzyme, and then digested with $X b a I$. The fragment was inserted into the PmeI and SpeI sites of the backbone of pLVTHM to produce the final plasmid pLV-hRluc. Lentivirus were produced using the same envelope plasmid as above and the packaging plasmid pCMV-dR8.91 (kind gift from Prof. D. Trono, EPFL, Switzerland).

\section{LV titration by limiting dilution}

Lentiviral particles at dilutions of $10^{-3}$ to $10^{-7}$ were used to infect HeLa cells in 6-well plates $(50,000$ cells/well). The medium was replaced after $48 \mathrm{~h}$ with a selection medium containing $2 \mu \mathrm{g} / \mathrm{ml}$ puromycin (Sigma). At day 12 post-infection cells were washed and stained with crystal violet, colonies were counted and lentiviral titer determined.

\section{Establishment of stably transduced cell lines}

pLV-CALB2 lentiviral vectors were used to stably express CR in different cell lines. Cells were tested for CR expression by Western Blot analysis using the CR antibody CR 7699/4 (Swant, Marly, Switzerland). MSTO$211 \mathrm{H}$ cells were infected with a lentivirus carrying the hRluc reporter gene. After each passage, cells were lysed and the stable and long-lasting expression of Renilla luciferase was measured using Renilla Juice (p.j.k.-GmbH, Kleinblittersdorf, Germany) in a Turner Designs TD-20/20
Luminometer (Sunnyvale, CA, USA) according to the manufacturer's protocol.

\section{Western blotting}

Protein extracts (cleared lysates) were obtained from cells grown to $70 \%$ confluence using standard RIPA buffer (50 mM Tris, $150 \mathrm{mM} \mathrm{NaCl,} \mathrm{0.1 \%} \mathrm{sodium} \mathrm{dodecyl}$ sulfate (SDS), $0.5 \%$ sodium deoxycholate, $1 \%$ Triton $\mathrm{X}-100, \mathrm{pH}$ 7.4) containing protease inhibitor cocktail (Quartett $\mathrm{GmbH}$, Berlin, Germany) and $1 \mathrm{mM}$ sodium orthovanadate $\left(\mathrm{Na}_{3} \mathrm{VO}_{4}\right.$; Sigma). Cells were collected using a cell scraper, incubated on ice for 5-10 min and centrifuged at $12,000 \mathrm{x} \mathrm{g}$ for $20 \mathrm{~min}$ at $4^{\circ} \mathrm{C}$. Proteins $(40$ $\mu \mathrm{g})$ were separated by $10 \%$ SDS-PAGE, transferred onto nitrocellulose membranes [7], blocked with 5\% BSA in TBS-Tween for $1 \mathrm{~h}$ and incubated overnight at $4^{\circ} \mathrm{C}$ with the following primary antibodies diluted in 2\% BSA: rabbit polyclonal anti-Calretinin (1:10,000; CR 7699/4), rabbit polyclonal anti-FAK $(1: 1,000$; Cell Signaling Technology, Danvers, MA, USA), rabbit polyclonal antip-FAK Tyr ${ }^{397}$ (1:1,000; Cell Signaling Technology), and rabbit polyclonal anti-GAPDH (1:5,000; Sigma); followed by incubation with secondary goat anti-rabbit or antimouse (HRP)-labeled antibodies (Sigma) at a dilution of 1:10,000. The signals were detected as described in [7]. For the EMT analysis membranes were incubated overnight at $4{ }^{\circ} \mathrm{C}$ with a rabbit monoclonal anti-E-cadherin antibody (1:1,000; \#3195; Cell Signaling Technology) and a mouse monoclonal N-cadherin $(1: 1,000$; \# 610920; BD Bioscience).

\section{Migration/proliferation and invasion assays}

A 'scratch wound assay' was performed in both cases. Cells were grown to confluence in 96-well ImageLock plates (Essen Bioscience Inc., Ann Arbor, Michigan, USA) pre-coated with a thin layer of $0.1 \mathrm{mg} /$ $\mathrm{ml}$ Matrigel Basement Membrane Matrix (Corning, Cat. No.354234). A scratch of about $1 \mathrm{~mm}$ width was created using the 96 well-plate woundmaker tool (Essen Bioscience) as described by the manufacturer. For the migration/proliferation assay, cells repopulating the scratch area grew directly on the surface of the ImageLock plates. In the case of the invasion assay, $50 \mu \mathrm{l}$ of $1 \mathrm{mg} /$ $\mathrm{ml}$ of Matrigel Basement Membrane Matrix (10-times higher concentration as the layer on which cells initially grew; for details see Supplemental Methods) was added to each well after the scratch, and cells were incubated for $30 \mathrm{~min}$. Finally $100 \mu \mathrm{l}$ of medium was added on top of the cells and plates were scanned at a 2-h frequency using the Incucyte $^{\mathrm{TM}}$ Live-cell Imaging System (Essen Bioscience). Images were evaluated with the IncuCyte ${ }^{\mathrm{TM}}$ software system. The Transwell invasion assay is described in detail in the Supplemental Methods. 


\section{Immunofluorescence}

Cells were seeded on 12-mm glass coverslips and fixed for 15 min with 4\% paraformaldehyde when they had reached approximately $60-70 \%$ confluence, blocked with TBS-containing donkey serum (10\%) and incubated overnight at $4{ }^{\circ} \mathrm{C}$ with the following antibodies diluted in TBS 1X: goat polyclonal anti-Calretinin (1:500; cat\#CG1, Swant) and anti-FAK (1:50; Cell Signaling). After washing, the cell-containing coverslips were incubated for $3 \mathrm{~h}$ at room temperature with the following secondary antibodies: Alexa Fluor 488-conjugated donkey anti-rabbit IgG (1:100; Jackson Immunoresearch Laboratories, West Grove, PA, USA) and Cy5-conjugated donkey anti-goat IgG (1:100; Jackson Immunoresearch Laboratories). Nuclear DNA was stained using DAPI (5 $\mu \mathrm{g} / \mathrm{ml}$; Molecular Probes, Eugene, OR) and coverslips were mounted with Hydromount solution (National Diagnostics, Atlanta, GA). Images were acquired using a LEICA fluorescent microscope DM6000B (Wetzlar, Germany) equipped with a Hamamatsu camera C4742-95 (Bridgewater, NJ).

\section{Subcellular fractionation and Western blotting}

Nuclear and cytoplasmic protein fractions were prepared using the Nuclear Extraction KIT (\#ab113474, Abcam) following the manufacturer's instructions. Equal amounts $(40 \mu \mathrm{g})$ were separated by $12.5 \%$ SDS-PAGE. Membranes were probed with anti-Calretinin (1:10,000; CR 7699/4), anti-FAK (1:1,000), rabbit monoclonal antiHistone H3 (1:1,000; Cell Signaling Technology) and rabbit polyclonal anti- $\alpha$-Tubulin $(1: 1,000$; Cell Signaling Technology).

\section{Co-immunoprecipitation (Co-IP)}

Cells (70-90\% confluence) were lysed with $1 \mathrm{ml}$ ice-cold lysis buffer $(150 \mathrm{mM} \mathrm{NaCl}, 1 \%$ Triton X-100, $50 \mathrm{mM}$ Tris $\mathrm{HCl}, \mathrm{pH}$ 8.0) supplemented with protease and phosphatase inhibitors. Following $30 \mathrm{~min}$ incubation cells were centrifuged $\left(10,000 \times \mathrm{g}\right.$ for $10 \mathrm{~min}$ at $\left.4^{\circ} \mathrm{C}\right) .50 \mu \mathrm{L}$ of supernatant was aliquoted for total cell lysate analysis. To pull down calretinin, 2-4 $\mu \mathrm{g}$ of the anti-CR antiserum CR 7699/4 was added to the remaining supernatant. 100 $\mu \mathrm{l}$ of $\mu \mathrm{MACS}$ protein A MicroBeads (Miltenyi Biotec, Auburn, USA) were added to the lysate and incubated at $4^{\circ} \mathrm{C}$ for $30 \mathrm{~min}$. Samples were loaded on MACS separation columns (Miltenyi Biotec) and subjected to magnetic immunoprecipitation. The columns were washed 3 times with a wash buffer (150 mM NaCl, 1\% NP-40, $0.5 \%$ sodium deoxycholate, $0.1 \% \mathrm{SDS}, 50 \mathrm{mM}$ Tris $\mathrm{HCl}$, $\mathrm{pH} 8.0$ ) and protein complexes were eluted in $50 \mu \mathrm{L}$ of pre-warmed SDS gel loading buffer $1 \mathrm{X}(50 \mathrm{mM}$ Tris $\mathrm{HCl}$, pH 6.8, $50 \mathrm{mM}$ DTT, 1\%SDS, 0.005\% bromophenol blue, $10 \%$ glycerol), subjected to electrophoresis (SDSPAGE) and subsequent Western Blotting. Normal rabbit polyclonal IgG (3 $\mu$ l \#12-370, Merck Millipore, Darmstadt, Germany) was used as a non-specific control for the co-IP experiments. Membranes were probed with anti-Calretinin (1:10,000; CR 7699/4), anti-FAK $(1: 1,000)$ and mouse monoclonal anti-Paxillin $(1: 2,000$; BD Bioscience).

\section{FAK inhibitor treatment and viability assays (MTT)}

3,000 cells/well were seeded in 96-well plates (TPP) and grown for $48 \mathrm{~h}$. The FAK inhibitor Defactinib (VS6063, PF-04554878, Selleckchem, Houston, USA) was solubilized in dimethyl sulfoxide (DMSO) and added in a concentration range from 2.5 to $10 \mu \mathrm{M}$. The MTT assay was performed after $48 \mathrm{~h}-72 \mathrm{~h}$ to determine the number of viable and proliferating cells [30]. The same concentration of DMSO without the inhibitor was used as a vehicle control.

\section{Pathway-specific PCR array}

Total RNA was isolated using the RNeasy mini kit (Qiagen, Germany) and reverse-transcribed into single stranded cDNA using the RT ${ }^{2}$ First Strand Kit (Qiagen) following the manufacturer's instructions. Differential expression of EMT genes was analyzed using a $\mathrm{RT}^{2}$ profiler PCR array specific for EMT Pathway (PAHS090ZR-12, Qiagen). Quantitative real-time PCRs (qPCR) were performed in a DNA thermal cycler (Corbett Rotor gene 6000, QIAGEN Instruments AG, Hombrechtikon, Switzerland). The following thermal profile was applied: 1 cycle at $95{ }^{\circ} \mathrm{C}$ for $10 \mathrm{~min}, 40$ cycles at $95{ }^{\circ} \mathrm{C}$ for $15 \mathrm{~s}$ and $60^{\circ} \mathrm{C}$ for $30 \mathrm{~s}$. Differences in fold expression were calculated following the $2^{-\Delta \Delta \mathrm{Ct}}$ method [51].

\section{Downregulation of CR and GFP expression in MSTO-211H cells using lentiviral-mediated shRNA in vitro}

MSTO-211H cells $(25,000 /$ well $)$ were seeded into 6-well plates and grown for $24 \mathrm{~h}$. LV containing a CALB2 or a GFP shRNA were added with a multiplicity of infection (MOI) of $10.72 \mathrm{~h}$ later cells were collected and $30 \mu \mathrm{g}$ of protein extract was subjected to $10 \% \mathrm{SDS}-\mathrm{PAGE}$ and subsequent Western Blotting.

\section{Downregulation of CR and GFP expression in MSTO in an orthotopic mouse model}

NOD SCID gamma (NSG) mice were utilized (4 mice per group). All experiments were performed with permission of the local animal care committee (Canton of Fribourg, Switzerland) and according to the present Swiss law and the European Communities Council Directive of 24 November 1986 (86/609/EEC). Briefly, MSTO- 
$211 \mathrm{H}-\mathrm{R}$ luc cells were transduced for $24 \mathrm{~h}$ with a lentiviral vector containing either an shRNA against GFP (control group) or against $C A L B 2$ (test group) at a MOI of 10 . Mice were separated into two groups and injected with cells pre-treated with shGFP or with shCALB2. Direct intraperitoneal (i.p.) injection of $1.5 \times 10^{6}$ tumor cells in $200 \mu \mathrm{l}$ PBS serum-free media was performed and mice were scanned at days 16 and 30 post-injection in order to follow tumor progression with the IVIS Lumina II In Vivo Imaging System (Caliper Life Sciences, Hopkinton, USA). For the Renilla luciferase detection imaging, 1 $\mathrm{mg} / \mathrm{kg}$ ViviRen ${ }^{\mathrm{TM}}$ In Vivo Renilla Luciferase Substrate (Cat\#P1231; Promega, Dübendorf, Switzerland) was injected i.p. before imaging. Images were acquired for 5-30 seconds depending on signal strength. Luminescence of the tumor was quantitatively evaluated using the Living Image 4.2 Software and the BLI signal was reported as photons $/ \mathrm{s} / \mathrm{cm}^{2} / \mathrm{sr}$. Organ samples were collected (diaphragm and parietal layer) for histological analysis.

\section{Immunohistochemistry}

Sections $(3 \mu \mathrm{m})$ were de-paraffinized and treated with Tris/EDTA ( $1 \mathrm{mM} / 0.1 \mathrm{mM}, \mathrm{pH}$ ) for the antigen retrieval by heating the sections in boiling water for 20 min, followed by 20 min incubation with $0.3 \%$ hydrogen peroxide. Then tissue was permeabilized with $0.1 \%$ PBSTween and blocked with PBS containing 2\% BSA and $1 \%$ bovine serum for $1 \mathrm{~h}$. Sections were incubated with a primary antibody rabbit polyclonal anti-Calretinin (1:500; CR 7699/4) or a mouse monoclonal anti-FAK antibody (1:200; clone 4.47, Merck Millipore) overnight at $4^{\circ} \mathrm{C}$. The next day, sections were incubated with a secondary biotinylated antibody $(1: 200)$ at room temperature for 2 $h$ and with VECTASTAIN® Elite ABC reagent (Vector Laboratories, Servion, Switzerland) for another $3 \mathrm{~h}$. DAB (Sigma) staining was followed by hematoxylin counterstaining. Slides were scanned using a whole-slide imaging system from Hamamatsu (Nanozoomer, 2.0HT).

\section{Statistical analysis}

MTT results from at least 3 independent experiments were pooled together; each sample was measured in triplicates. Mean and standard deviation are shown in the figures. The statistical significance of all the experiments was calculated with the GraphPad Prism software (GraphPad Software Inc., San Diego, CA, USA). A two way-ANOVA was used to analyze the FAK inhibitor (factors: dose and CR expression) and the orthotopic mouse model experiments (factors: treatment shCALB2/ shGFP and time). In both cases a Sidak's multiple comparison was used as post-hoc test. A one sample t-test (two-sided) was performed to quantify the protein levels of nuclear FAK and p-FAK ( $\mathrm{Tyr}^{397}$ ), and for the comparison of the wound closure times. Differences with p-values of less than 0.05 were considered significant.

\section{Abbreviations}

CR: calretinin; FAK: focal adhesion kinase; MM: malignant mesothelioma; EMT: epithelial-tomesenchymal transition; ECM: extracellular matrix; BLI: bioluminescent imaging.

\section{Author contributions}

BS conceived the study, participated in the data analyses and in the writing of the manuscript. JW carried out the acquisition of data, performed the data analyses and writing of the manuscript. VS contributed in the acquisition of data. WB and LP set up the BLI (pLVhRluc) orthotopic mouse model system. All authors read and approved the final manuscript.

\section{ACKNOWLEDGMENTS}

The authors wish to thank A. Oberson, M. Steinauer, M. Sanchez, S. Eichenberger, and F. Meyenhofer, University of Fribourg, for their excellent technical assistance; and T. Henzi and F. Filice, University of Fribourg, for feedback on the manuscript.

\section{CONFLICTS OF INTEREST}

The authors declare that they have no conflicts of interest with the contents of this article.

\section{FUNDING}

The project was supported by the Swiss National Science Foundation (SNF grants \#130680, R'Equip grant \#139226 and Sinergia grant \#147697/1).

\section{REFERENCES}

1. Carbone M, Ly BH, Dodson RF, Pagano I, Morris PT, Dogan UA, Gazdar AF, Pass HI, Yang H. Malignant mesothelioma: facts, myths, and hypotheses. J Cell Physiol. 2012; 227:44-58. https://doi.org/10.1002/ jcp. 22724

2. Vogelzang NJ, Rusthoven JJ, Symanowski J, Denham C, Kaukel E, Ruffie P, Gatzemeier U, Boyer M, Emri S, Manegold C, Niyikiza C, Paoletti P. Phase III study of pemetrexed in combination with cisplatin versus cisplatin alone in patients with malignant pleural mesothelioma. J Clin Oncol. 2003; 21:2636-44. https://doi.org/10.1200/ JCO.2003.11.136

3. Hjerpe A, Dobra K. Malignant mesothelioma - a connective tissue tumor with proteoglycan-dependent differentiation. 
Connect Tissue Res. 2008; 49:249-51. https://doi. org/10.1080/03008200802147761

4. Travis WD, Brambilla E, Müller-Hermelink HK, Harris CC. Pathology and genetics of tumours of the lung, pleura, thymus and heart. Lyon: IARC Press; 2004.

5. Gotzos V, Vogt P, Celio MR. The calcium binding protein calretinin is a selective marker for malignant pleural mesotheliomas of the epithelial type. Pathol Res Pract. 1996; 192:137-47. https://doi.org/10.1016/ S0344-0338(96)80208-1

6. Doglioni C, Dei Tos AP, Laurino L, Iuzzolino $\mathrm{P}$, Chiarelli C, Celio MR, Viale G. Calretinin: a novel immunocytochemical marker for mesothelioma. Am J Surg Pathol. 1996; 20:1037-46. https://doi. org/10.1097/00000478-199609000-00001

7. Blum W, Schwaller B. Calretinin is essential for mesothelioma cell growth/survival in vitro: a potential new target for malignant mesothelioma therapy? Int J Cancer. 2013; 133:2077-88. https://doi.org/10.1002/ ijc. 28218

8. Henzi T, Blum WV, Pfefferli M, Kawecki TJ, Salicio V, Schwaller B. SV40-induced expression of calretinin protects mesothelial cells from asbestos cytotoxicity and may be a key factor contributing to mesothelioma pathogenesis. Am J Pathol. 2009; 174:2324-36. https://doi. org/10.2353/ajpath.2009.080352

9. Billing-Marczak K, Ziemińska E, Leśniak W, Łazarewicz JW, Kuźnicki J. Calretinin gene promoter activity is differently regulated in neurons and cancer cells. Role of AP2-like cis element and zinc ions. Biochim Biophys Acta. 2004; 1678:14-21. https://doi.org/10.1016/j. bbaexp.2004.01.004

10. Zhao J, Guan JL. Signal transduction by focal adhesion kinase in cancer. Cancer Metastasis Rev. 2009; 28:35-49. https://doi.org/10.1007/s10555-008-9165-4

11. Zhou S, Liu L, Li H, Eilers G, Kuang Y, Shi S, Yan Z, Li X, Corson JM, Meng F, Zhou H, Sheng Q, Fletcher JA, Ou WB. Multipoint targeting of the PI3K/mTOR pathway in mesothelioma. Br J Cancer. 2014; 110:2479-88. https://doi. org/10.1038/bjc.2014.220

12. Lee BY, Timpson P, Horvath LG, Daly RJ. FAK signaling in human cancer as a target for therapeutics. Pharmacol Ther. 2015; 146:132-49. https://doi.org/10.1016/j. pharmthera.2014.10.001

13. Thiery JP, Sleeman JP. Complex networks orchestrate epithelial-mesenchymal transitions. Nat Rev Mol Cell Biol. 2006; 7:131-42. https://doi.org/10.1038/nrm1835

14. Kalluri R, Weinberg RA. The basics of epithelialmesenchymal transition. J Clin Invest. 2009; 119:1420-28. https://doi.org/10.1172/JCI39104

15. Servais EL, Colovos C, Rodriguez L, Bograd AJ, Nitadori J, Sima C, Rusch VW, Sadelain M, Adusumilli PS. Mesothelin overexpression promotes mesothelioma cell invasion and MMP-9 secretion in an orthotopic mouse model and in epithelioid pleural mesothelioma patients. Clin Cancer Res. 2012; 18:2478-89. https://doi.org/10.1158/1078-0432. CCR-11-2614

16. Guy JB, Espenel S, Vallard A, Battiston-Montagne P, Wozny AS, Ardail D, Alphonse G, Rancoule C, Rodriguez-Lafrasse C, Magne N. Evaluation of the Cell Invasion and Migration Process: A Comparison of the Video Microscope-based Scratch Wound Assay and the Boyden Chamber Assay. J Vis Exp. 2017. https://doi. org/10.3791/56337

17. Owens LV, Xu L, Craven RJ, Dent GA, Weiner TM, Kornberg L, Liu ET, Cance WG. Overexpression of the focal adhesion kinase (p125FAK) in invasive human tumors. Cancer Res. 1995; 55:2752-55.

18. Gabarra-Niecko V, Schaller MD, Dunty JM. FAK regulates biological processes important for the pathogenesis of cancer. Cancer Metastasis Rev. 2003; 22:359-74. https:// doi.org/10.1023/A:1023725029589

19. Infante JR, Camidge DR, Mileshkin LR, Chen EX, Hicks RJ, Rischin D, Fingert H, Pierce KJ, Xu H, Roberts WG, Shreeve SM, Burris HA, Siu LL. Safety, pharmacokinetic, and pharmacodynamic phase I dose-escalation trial of PF-00562271, an inhibitor of focal adhesion kinase, in advanced solid tumors. J Clin Oncol. 2012; 30:1527-33. https://doi.org/10.1200/JCO.2011.38.9346

20. Roberts WG, Ung E, Whalen P, Cooper B, Hulford C, Autry C, Richter D, Emerson E, Lin J, Kath J, Coleman K, Yao L, Martinez-Alsina L, et al. Antitumor activity and pharmacology of a selective focal adhesion kinase inhibitor, PF-562,271. Cancer Res. 2008; 68:1935-44. https://doi. org/10.1158/0008-5472.CAN-07-5155

21. Boyer B, Vallés AM, Edme N. Induction and regulation of epithelial-mesenchymal transitions. Biochem Pharmacol. 2000; 60:1091-99. https://doi.org/10.1016/ S0006-2952(00)00427-5

22. Yoon H, Dehart JP, Murphy JM, Lim ST. Understanding the roles of FAK in cancer: inhibitors, genetic models, and new insights. J Histochem Cytochem. 2015; 63:114-28. https://doi.org/10.1369/0022155414561498

23. Blum W, Pecze L, Felley-Bosco E, WorthmüllerRodriguez J, Wu L, Vrugt B, de Perrot M, Schwaller B. Establishment of immortalized murine mesothelial cells and a novel mesothelioma cell line. In Vitro Cell Dev Biol Anim. 2015; 51:714-21. https://doi.org/10.1007/s11626015-9885-z. Erratum in: Erratum to: Establishment of immortalized murine mesothelial cells and a novel mesothelioma cell line. [In Vitro Cell Dev Biol Anim. 2017].

24. Chen LJ, Ye H, Zhang Q, Li FZ, Song LJ, Yang J, Mu Q, Rao SS, Cai PC, Xiang F, Zhang JC, Su Y, Xin JB, Ma WL. Bleomycin induced epithelial-mesenchymal transition (EMT) in pleural mesothelial cells. Toxicol Appl Pharmacol. 2015; 283:75-82. https://doi.org/10.1016/j. taap.2015.01.004 
25. Lamouille S, Xu J, Derynck R. Molecular mechanisms of epithelial-mesenchymal transition. Nat Rev Mol Cell Biol. 2014; 15:178-96. https://doi.org/10.1038/nrm3758

26. Wu YJ, La Pierre DP, Wu J, Yee AJ, Yang BB. The interaction of versican with its binding partners. Cell Res. 2005; 15:483-94. https://doi.org/10.1038/sj.cr.7290318

27. Jean D, Daubriac J, Le Pimpec-Barthes F, Galateau-Salle F, Jaurand MC. Molecular changes in mesothelioma with an impact on prognosis and treatment. Arch Pathol Lab Med. 2012; 136:277-93. https://doi.org/10.5858/ arpa.2011-0215-RA

28. Wang H, Gillis A, Zhao C, Lee E, Wu J, Zhang F, Ye F, Zhang DY. Crocidolite asbestos-induced signal pathway dysregulation in mesothelial cells. Mutat Res. 2011; 723:171-76. https://doi.org/10.1016/j. mrgentox.2011.04.008

29. Blum W, Pecze L, Felley-Bosco E, Schwaller B. Overexpression or absence of calretinin in mouse primary mesothelial cells inversely affects proliferation and cell migration. Respir Res. 2015; 16:153. https://doi. org/10.1186/s12931-015-0311-6

30. Marilley D, Vonlanthen S, Gioria A, Schwaller B. Calretinin and calretinin-22k increase resistance toward sodium butyrate-induced differentiation in CaCo- 2 colon adenocarcinoma cells. Exp Cell Res. 2001; 268:93-103. https://doi.org/10.1006/excr.2001.5261

31. Häner K, Henzi T, Pfefferli M, Künzli E, Salicio V, Schwaller B. A bipartite butyrate-responsive element in the human calretinin (CALB2) promoter acts as a repressor in colon carcinoma cells but not in mesothelioma cells. J Cell Biochem. 2010; 109:519-31.

32. Kresoja-Rakic J, Kapaklikaya E, Ziltener G, Dalcher D, Santoro R, Christensen BC, Johnson KC, Schwaller B, Weder W, Stahel RA, Felley-Bosco E. Identification of cisand trans-acting elements regulating calretinin expression in mesothelioma cells. Oncotarget. 2016; 7:21272-86. https:// doi.org/10.18632/oncotarget.7114

33. Hucl T, Brody JR, Gallmeier E, Iacobuzio-Donahue CA, Farrance IK, Kern SE. High cancer-specific expression of mesothelin (MSLN) is attributable to an upstream enhancer containing a transcription enhancer factor dependent MCAT motif. Cancer Res. 2007; 67:9055-65. https://doi. org/10.1158/0008-5472.CAN-07-0474

34. Robinson C, van Bruggen I, Segal A, Dunham M, Sherwood A, Koentgen F, Robinson BW, Lake RA. A novel SV40 TAg transgenic model of asbestos-induced mesothelioma: malignant transformation is dose dependent. Cancer Res. 2006; 66:10786-94. https://doi.org/10.1158/0008-5472. CAN-05-4668

35. Frame MC, Patel H, Serrels B, Lietha D, Eck MJ. The FERM domain: organizing the structure and function of FAK. Nat Rev Mol Cell Biol. 2010; 11:802-14. https://doi. org/10.1038/nrm2996
36. Naser R, Aldehaiman A, Díaz-Galicia E, Arold ST. Endogenous Control Mechanisms of FAK and PYK2 and Their Relevance to Cancer Development. Cancers (Basel). 2018; 10:10. https://doi.org/10.3390/ cancers 10060196

37. Blum W, Pecze L, Rodriguez JW, Steinauer M, Schwaller B. Regulation of calretinin in malignant mesothelioma is mediated by septin 7 binding to the CALB2 promoter. BMC Cancer. 2018; 18:475. https://doi.org/10.1186/ s12885-018-4385-7

38. Kresoja-Rakic J, Sulemani M, Kirschner MB, Ronner M, Reid G, Kao S, Schwaller B, Weder W, Stahel RA, Felley-Bosco E. Posttranscriptional Regulation Controls Calretinin Expression in Malignant Pleural Mesothelioma. Front Genet. 2017; 8:70. https://doi.org/10.3389/ fgene.2017.00070

39. Christel CJ, Schaer R, Wang S, Henzi T, Kreiner L, Grabs D, Schwaller B, Lee A. Calretinin regulates Ca2+dependent inactivation and facilitation of $\mathrm{Ca}(\mathrm{v}) 2.1 \mathrm{Ca} 2+$ channels through a direct interaction with the $\alpha 12.1$ subunit. J Biol Chem. 2012; 287:39766-75. https://doi.org/10.1074/ jbc.M112.406363

40. Dong G, Gross K, Qiao F, Ferguson J, Callegari EA, Rezvani K, Zhang D, Gloeckner CJ, Ueffing M, Wang H. Calretinin interacts with huntingtin and reduces mutant huntingtincaused cytotoxicity. J Neurochem. 2012; 123:437-46. https://doi.org/10.1111/j.1471-4159.2012.07919.x

41. Schwaller B. Calretinin: from a "simple" $\mathrm{Ca}(2+)$ buffer to a multifunctional protein implicated in many biological processes. Front Neuroanat. 2014; 8:3. https://doi. org/10.3389/fnana.2014.00003

42. Schaller MD. Paxillin: a focal adhesion-associated adaptor protein. Oncogene. 2001; 20:6459-72. https://doi. org/10.1038/sj.onc. 1204786

43. Brown MC, Curtis MS, Turner CE. Paxillin LD motifs may define a new family of protein recognition domains. Nat Struct Biol. 1998; 5:677-78. https://doi. org/10.1038/1370

44. Brown MC, Perrotta JA, Turner CE. Identification of LIM3 as the principal determinant of paxillin focal adhesion localization and characterization of a novel motif on paxillin directing vinculin and focal adhesion kinase binding. J Cell Biol. 1996; 135:1109-23. https://doi.org/10.1083/ jcb.135.4.1109

45. Thomas JW, Cooley MA, Broome JM, Salgia R, Griffin JD, Lombardo CR, Schaller MD. The role of focal adhesion kinase binding in the regulation of tyrosine phosphorylation of paxillin. J Biol Chem. 1999; 274:36684-92. https://doi. org/10.1074/jbc.274.51.36684

46. Lim ST, Chen XL, Lim Y, Hanson DA, Vo TT, Howerton K, Larocque N, Fisher SJ, Schlaepfer DD, Ilic D. Nuclear FAK promotes cell proliferation and survival through FERMenhanced p53 degradation. Mol Cell. 2008; 29:9-22. https:// doi.org/10.1016/j.molcel.2007.11.031 
47. Serrels A, Lund T, Serrels B, Byron A, McPherson RC, von Kriegsheim A, Gómez-Cuadrado L, Canel M, Muir M, Ring JE, Maniati E, Sims AH, Pachter JA, et al. Nuclear FAK controls chemokine transcription, Tregs, and evasion of anti-tumor immunity. Cell. 2015; 163:160-73. https://doi. org/10.1016/j.cell.2015.09.001

48. Mitra SK, Hanson DA, Schlaepfer DD. Focal adhesion kinase: in command and control of cell motility. Nat Rev Mol Cell Biol. 2005; 6:56-68. https://doi.org/10.1038/ nrm1549

49. Mitra SK, Schlaepfer DD. Integrin-regulated FAKSrc signaling in normal and cancer cells. Curr Opin Cell Biol. 2006; 18:516-23. https://doi.org/10.1016/j. ceb.2006.08.011
50. Schmitter D, Lauber B, Fagg B, Stahel RA. Hematopoietic growth factors secreted by seven human pleural mesothelioma cell lines: interleukin-6 production as a common feature. Int J Cancer. 1992; 51:296-301. https:// doi.org/10.1002/ijc.2910510220

51. Schmittgen TD, Livak KJ. Analyzing real-time PCR data by the comparative C(T) method. Nat Protoc. 2008; 3:1101-08. https://doi.org/10.1038/nprot.2008.73 